\title{
The Use, Impact, and Unintended Consequences of Mobile Web-Enabled Devices in University Classrooms
}

\author{
Kevin A. Johnston \\ University of Cape Town, South Africa
}

\section{Kevin.johnston@uct.ac.za}

\begin{abstract}
The impact that mobile web-enabled devices have had on the lives and behavior of university students has been immense. Yet, many of the models used in the classrooms have remained unchanged. Although a traditional research approach of examining the literature, developing a methodology, and so on is followed, this paper's main aim is to inform practitioners on observations and examples from courses which insist on and encourage mobiles in the classroom.

The paper asked three research questions regarding the use, impact, and unintended consequences of mobile web-enabled devices in the classroom. Data was collected from observing and interacting with post graduate students and staff in two universities across two continents: Africa and Europe.

The paper then focuses on observations and examples on the use, impact, and unintended consequences of mobile web-enabled devices in two classrooms. The findings are that all students used mobile web-enabled devices for a variety of reasons. The use of mobile devices did not negatively impact the class, rather students appeared to be more engaged and comfortable knowing they were allowed to openly access their mobile devices. The unintended consequences included the use of mobiles to translate text into home languages.
\end{abstract}

Keywords: Mobile web-enabled devices, Usage, Impact, Unintended consequences, University Students, Social Network Systems (SNS).

\section{Introduction}

There is a fair bit written and spoken about the impact of mobile web-enabled devices on the lives and social behavior of people (Ley et al., 2014; Morgan \& Ravindran, 2014). Gerpott and Thomas $(2014$, p.291) reviewed " 175 scholarly empirical publications on mobile Internet (MI) usage

Material published as part of this publication, either on-line or in print, is copyrighted by the Informing Science Institute. Permission to make digital or paper copy of part or all of these works for personal or classroom use is granted without fee provided that the copies are not made or distributed for profit or commercial advantage AND that copies 1) bear this notice in full and 2) give the full citation on the first page. It is permissible to abstract these works so long as credit is given. To copy in all other cases or to republish or to post on a server or to redistribute to lists requires specific permission and payment of a fee. Contact Publisher@InformingScience.org to request redistribution permission. intensity levels and potential determinants of respective usage behavior at the individual subscriber level." Several papers have been written on the use of mobile devices for learning (Alarabiat \& Al-Mohammad, 2015; Coldwell, Craig \& Goold, 2011; Jovanovic \& Chiong, 2012), and teaching (Barjis et al., 2012; Jovanovic, Chiong \& Weise, 2012). Many university students consider the use of Social Network Systems (SNS) 
such as Facebook and Twitter as part of their daily routine (Alarabiat \& Al-Mohammad, 2015; Johnston, 2013). University students used their mobile web-enabled devices on campus for a variety of activities, which included Information gathering, Socializing on Facebook, Academic work, Course related administration, and Recreation such as playing games, listening to music, and watching videos (Alarabiat \& Al-Mohammad, 2015; Johnston, 2013).

One of the educational paradoxes is that university students see and use mobile web-enabled devices everywhere in their lives but in the classroom (Johnston, 2013). Many of the teaching and learning models used in classrooms have remained unchanged; there are however instances where mobile web-enabled devices have been used successfully in classrooms (Carter, 2014; Johnston, 2013).

Rather than follow a traditional research approach of examining the literature, developing a methodology, and so on, this paper examines and reports on observations on two post graduate courses which insist on the use of mobiles in the classroom. The observations were made at two universities: one in South Africa, and one in Germany.

The purpose of the research was to investigate the usage, impact, and unintended consequences of mobile web-enabled devices in the classroom. The research aimed to gain familiarity and new insight into the usage and impact of mobile web-enabled devices among university students while in the classroom.

\section{Literature Review}

Literature was sourced from academic journals and Google Scholar, using the Interdisciplinary Journal of Information, Knowledge, and Management as a starting point. The literature review covers three main themes: the use, the impact, and the unexpected consequences of mobile webenabled devices in the classroom.

\section{Use of Mobile Web-Enabled Devices in the Classroom}

There is a growing expectation for academics to learn and include mobile web-enabled devices within teaching, learning, and administrative spaces (Johnston, 2013). "Survey research and public polling data indicate that the majority of college students not only have mobile phones, but also bring them to class and use them in class on a regular basis" (Kuznekoff, Munz, \& Titsworth, 2015, p. 345).

Several papers have covered the use of mobile web-enabled devices for learning (Alarabiat \& AlMohammad, 2015; Coldwell et al., 2011; Hwang \& Chang, 2011; Jovanovic \& Chiong, 2012), and teaching (Barjis et al., 2012; Jovanovic et al., 2012; Ruggiero \& Mong, 2015). Many students expect and would like to use technology whilst in class (Johnston, 2013), and some teachers believe students should be allowed to use mobile web-enabled devices in class (Ruggiero \& Mong, 2015).

Coldwell et al. (2011) provide a useful categorization of technologies and applications which could be used by mobile web-enabled devices in a course and in a classroom. The categorization (Coldwell et al., 2011) and some examples of applications are shown in Table 1.

Learning Management Systems (LMS) such as Moodle and Sakai have a range of applications and fit into several technology categories. Most LMSs are continually evolving and providing additional functionality and services (Conde et al., 2014). LMS's integrate several applications, and put the student at the centre of the process, many LMSs also facilitate students collaborating to define the contents and are accessible from a mobile web-enabled device (Conde et al., 2014). 
Table 1: Categorization of technologies (Coldwell et al., 2011) and examples of applications

\begin{tabular}{|l|l|}
\hline Technology Category & Examples of applications \\
\hline Assessment and Survey Tools & Mentimeter, Moodle and Sakai \\
\hline Podcasts, Vodcasts and Streaming & Camtasia and Sakai \\
\hline Social Networking Systems & FaceBook, Twitter \\
\hline Shared Documents & Dropbox, Google Docs, Moodle and Sakai \\
\hline Synchronous communication & Telephone calls, Skype and instant messaging \\
\hline Video sharing & Youtube, Moodle and Sakai \\
\hline Wiki & Wiki \\
\hline Virtual Worlds & Online roleplay apps such as Fablusi \\
\hline Gaming & \\
\hline
\end{tabular}

Assessment tools such as Mentimeter facilitate formative assessments, pop quizzes, asking openended questions, asking multiple choice questions (MCQs), and carrying out polls. Formative assessments allow academics to monitor student learning, and reinforce self-regulated learning (SRL) among students (Clark, 2012). "It was found that a formative approach to mobile learning stimulated SRL and revealed higher learning motivation and better learning achievement" (Clark, 2012, p. 227).

Podcasts (audio-only files synchronised with Power-Point) and Vodcasts (audio-video files synchronised with PowerPoint) can be made of classroom sessions and then posted onto a learning management system (LMS) such as Sakai (Johnston, 2013). Students may access the podcasts and vodcasts in whole or in part. In 2012, a class of 665 students downloaded 30 vodcasts 112696 times over a six month period (Johnston, 2013).

Research has shown that many students believe that using Social Networking Systems (SNS) such as Facebook and Twitter in class would be convenient (Alarabiat \& Al-Mohammad, 2015; Karl \& Peluchette, 2011; Roblyer, McDaniel, Webb, Herman, \& Witty, 2010), as these systems are an integral part of their daily lives (Alarabiat \& Al-Mohammad, 2015; Johnston, 2013). In a study of schools, Ruggiero and Mong (2015) found teachers used mobiles in the classroom to share ideas using social networking systems, as well as for email, attendance systems, and research. Alarabiat and Al-Mohammad (2015) explored the use of Facebook for learning in three Jordanian universities. Similarly to most students globally, the majority of Jordanian students were members of Facebook and spent a considerable amount of time daily on Facebook. Petersen and Johnston (2015) found 97\% of South African university students surveyed were members of Facebook and spent 1-2 hours a day on Facebook. While socializing and recreation were the main uses of Facebook, an increasing number of students were using Facebook for academic purposes such as arranging study groups and meetings (Alarabiat and Al-Mohammad, 2015; Johnston, Chen, \& Hauman, 2013).

Shared documents enable academics and students to synchronize, store, retrieve, and share documents and files across mobile devices and PCs. Academics and students are generally positive towards sharing documents using applications such as dropbox (Ishak, Yamin, \& Ibrahim, 2014). Students also accessed LMS such as Moodle using their mobiles in classrooms (Al Hamdani, 2014). Forums in which students post and read questions and answers may be considered a component of shared documents. Students are often not active members of the forum, i.e., they don't post questions or answers, but rather simply read others posts (Smith \& Smith, 2014).

Guerrero (2012) found that students used Skype for synchronous communication, particularly between native speakers and foreign language students. Students preferred to converse with native speakers rather than use language laboratories. In a language course, Al Hamdani (2014) 
found students used mobiles to translate texts, check spelling, look for vocabulary, and access a dictionary in class.

Although created as a video-sharing service for all users, YouTube has become part of many academics' and students' lives. Many academics are active participants and post, comment on, rate, and share videos with students (Roodt, de Villiers, Johnston, Ophoff \& Peier, 2014).

Wiki's have been found to make group work easier and more effective for students, and facilitate the management and marking of group work (Burton, 2015).

Hwang and Chang (2011, p. 1023) described mobile learning as when students participate "via mobile devices without being limited by space and time; in particular, the students can be situated in a real-world scenario associated with the learning content." Students can use online roleplay applications such as Fablusi.

Lekshmipriya, Kumar, Mahadevan, and Bijlani (2016) used the Wiimote gaming system for collaborative classroom activities, and students found learning fun and engaging. Gaming was found to encourage and augment student learning. "The core elements of games (rules, feedback systems, and voluntary participation) are integrated into the learning activities" (Brophy, 2015, p. 91). Brophy (2015) states that people are spending over 3 billion hours a week on online gaming, and that this number is expected to increase as individuals find gaming engaging, motivating, and fulfilling and can lead to the formation of strong ties among individuals within a social network.

University students were found to use mobile web-enabled devices for a range of activities, some of which could be in the classroom. The activities included gathering information on news, sports etc., Socializing on Facebook, Chatrooms, Instant Messaging etc., Academic work such as reading and studying, Course related administration on LMS, watching vodcasts, checking deliverable dates, submitting work etc., and Recreation such as playing games, listening to music, and watching videos (Alarabiat \& Al-Mohammad, 2015; Johnston, 2013).

The obvious question is who will provide and pay for mobile web-enabled devices in the classrooms? Benham, Carvalho and Cassens (2014) suggest that most if not all university students already own the necessary devices, and so a Bring Your own Device (BYOD) policy could be implemented at no additional costs other than supplying wifi. The main stumbling block students see is the inability and unwillingness of academics to use mobile web-enabled devices in the classroom (Benham et al., 2014).

The literature led to the first research question: How are mobile web-enabled devices used in classrooms in two Universities?

\section{Impact of Mobile Web-Enabled Devices in the Classroom}

Students understand the impact and benefits of using mobile web-enabled devices in the classroom and have a desire to increase the use of such devices in classrooms (Abachi \& Muhammad, 2014; Benham et al., 2014).

Kuznekoff et al. (2015) examined the effects of using mobile phones in a classroom and found that students who were allowed to text and Tweet in class scored significantly lower grades and scored lower on recalling information and note-taking. Messaging "unrelated to class content negatively impacted learning and note-taking, while related messages did not appear to have a significant negative impact" (Kuznekoff, et al., 2015, p. 344). The paper does however conclude with the sentence, "It does appear that appropriately integrating the use of these devices into class may help student learning" (Kuznekoff et al., 2015, p. 363).

Benham et al. (2014) and Carter (2014) found research which showed one of the impacts of using mobiles in class was improved student motivation and engagement, but that research was mixed 
with regard to learning outcomes. The use of technology may improve learning outcomes of low achieving students by improving motivation and engagement (Carter, 2014; Ley et al., 2014). Power (2014) states that there are a number of studies which show positive impacts on learning outcomes through the use of mobiles in the classroom. There are researchers such as Inal, Kelleci, and Canbulat (2012) who feel that mobile web-enabled devices actually impede student engagement by acting as a distraction.

Another impact is that technology such as mobile phones can make teaching more effective or more difficult in the classroom (Coldwell et al., 2011).

An impact on academics is they need to change and adapt their teaching to incorporate mobile web-enabled devices in the classroom. "Academics therefore need to adopt teaching methods which are interactive, social, visual, practical and immediate" (Johnston, 2013, p.271).

Wu, Outley, Matarrita-Cascante, and Murphrey $(2015$, p. 1) "suggest that adults who interact with youth should incorporate internet technology into their work, and consider the development of a digital landscape to promote adolescents social connectedness"

Ngafeeson and Sun (2015) suggest that academics should assist students with the implementation and use of new technology and applications by offering information and training which emphasizes what is in it for the students. In addition, institutions should ensure that circumstances and infrastructure facilitate the use of the systems, and that support is provided (Ngafeeson \& Sun, 2015). However, as these were both post graduate courses, the academic never had to assist students with the use of ICT, rather the students were able to assist the academic.

Other possible negative impacts could be security and privacy (Abachi \& Muhammad, 2014), yet Al Hamdani's (2014) students did not mention security or privacy as a concern when using mobiles in the classroom, rather slow internet connectivity, inconvenient word input and the keyboard were ranked as the top three problems. This led to the second research question: What is the impact of mobile web-enabled devices in classrooms in two Universities?

\section{Unintended Consequences of Mobile Web-Enabled Devices in the Classroom}

Unintended consequences may be defined "direct and indirect outcomes that are outside of expectations" (Franklin, 2015, p. 241). Unintended consequences of mobile web-enabled devices in the classroom may be positive or negative and may affect both students and academics.

The issue of explaining the consequences of technology use has been researched for many years (Markus \& Robey, 2004). "More often, occurrences of unintended consequences of technology use are noted as ironic anomalies or contradictions but they have not been directly addressed in the theoretical and empirical IS literature" (Markus \& Robey, 2004, p. 66).

The majority of Information Systems research has highlighted the positive consequences of technology use among people, particularly young people (Cobcroft, Towers, Smith \& Bruns, 2006; Munzur, 2013; Tarafdar, Gupta \& Turel, 2013; Wu, et al., 2015). Positive consequences include improved motivation and engagement of students (Carter, 2014; Ley et al., 2014), a heightened sense of social connectedness (Wu et al., 2015), improved collaboration, encourage independent learning, and support for students with social, behavioural and cognitive problems (Cobcroft et al., 2006). Junco and Cotton (2011) found that the use of mobile web-enabled devices in the teaching and learning processes created unintended social support. Research has also highlighted several negative consequences of technology use, including work-life balance, increased stress, lowliness, depression, and social isolation and anxiety (Fischer \& Smolnik, 2014; Wu et al., 2015). Mobile web-enabled devices can also be a distraction in a classroom and disrupt academic activity (Inal et al., 2012; Lepp, Barkley \& Karpinski, 2014). 
One unintended consequence is that academics have to build a new curricula that uses mobile web-enabled devices to enhance face-to-face teaching (Nursey-Bray, 2015). Academics must tutor students on the use of mobile web-enabled devices and be aware of overusing mobile webenabled devices in class (Nursey-Bray, 2015).

Two additional positive unintended consequences have been the move to paperless and 'green' classrooms (Ruggiero, \& Mong, 2015) and the transition to a more student-centered or 'flipped classroom' which allows students to watch a video of the lecture prior to (or during) the class, and engage in deeper discussion in the classroom (Bafna, 2014; Clark, 2012). This led to the third research question: What are the unintended consequences of mobile web-enabled devices in classrooms in two Universities?

\section{Research Methodology}

According to Saunders, Lewis, and Thornhill (2012), the research philosophy relates to the development of knowledge and the nature of the knowledge developed. The four research philosophies in management research are Positivism, Realism, Interpretivism, and Pragmatism (Saunders et al. (2012). This research is from an Interpretivism perspective, with the main aim of informing practitioners based on observations and examples from two Information Systems courses which insist and encourage mobile web-enabled devices in the classroom (Gill \& Bhattacherjee, 2009). The research method was to use two qualitative case studies (one in Germany, and one in South Africa) in which direct observations were made and examples shown in two classes as proposed by Gill and Bhattacherjee (2009). The class in Germany was an MBA class, while the one in South Africa was a fist year post graduate course ( $4^{\text {th }}$ year at University).

The Course Programs stated that the courses were as Green as possible, and that "there are almost no paper hand-ins or hand-outs - all deliverables and documents are electronic, including examinations." The programs further stated that, all students were expected to bring AT LEAST ONE mobile device to each class, and that the mobile MUST be on at all times in class. The program also stated that bonuses could be awarded for creating video content using mobiles. Thus students were aware before starting the course that mobiles would be part of classes.

\section{Examples and Observations}

The first step was to ascertain what devices students were going to be using in the classroom, following Al Hamdani (2014). On the first day of the course students were asked to indicate the Mobile Phone and Tablet they were in possession of. Rather than show the German class list, the South African class list is shown in Table 2 (only the first three letters of individual's first names have been shown). Note that all the students in the South African class had a mobile phone, which confirms Benham et al.'s (2014) assertion that all students own a mobile. The students in Germany all had mobile phones (mostly Apples and Samsung's), and 90\% had a tablet; of the South Africans over $72 \%$ had a tablet. 
Table 2: A class attendance list showing mobiles and tablets

\begin{tabular}{|c|c|c|}
\hline First name & Mobile Phone & Tablet \\
\hline Nta & Nokia Lumia 520 & Ipad \\
\hline All & Samsung S4 Mini & none \\
\hline Mak & Iphone $4 s$ & Ipad \\
\hline Rat & Samsung Galaxy S4 & Samsung Galaxy Tab 2 \\
\hline Sdu & Blackberry Z10 & none \\
\hline Gra & iPhone & Ipad \\
\hline Vin & iPhone 5 & none \\
\hline Dec & iPhone 5 & Ipad Air \\
\hline Ame & Apple, iPhone & Samsung, Galaxy Tab 2 \\
\hline Ban & BlackBerry Q10 & Kindle Fire \\
\hline Nom & Sony Xperia V LT25i & Samsung Galaxy Tab 4 \\
\hline Sha & BLackberry z10 & Huawei \\
\hline Cam & Samsung Galaxy S4 mini & IPad 2 \\
\hline Lou & Samsung Galaxy S5 & Huawei \\
\hline Nay & iPhone 4 & Kindle Fire \\
\hline Joa & Iphone 5c & Ipad Air \\
\hline Mab & Samsung & Huawei Youth 7 tablet \\
\hline Flo & Apple Iphone 6 & none \\
\hline Jas & Sony Xperia Z1 & iPad 2 \\
\hline Yus & Samsung I9500 Galaxy S4 & iPad 2 \\
\hline Jam & iphone5 & none \\
\hline Raw & Htc desire & none \\
\hline Far & iPhone 5 & None \\
\hline Mad & sumsung note 3 & None \\
\hline Zuz & \multicolumn{2}{|c|}{ Samsung galaxy S4 GT-I9500 Samsung galaxy 10.1 tab 2} \\
\hline Mal & Huawei Ascend & Huawei \\
\hline Man & Samsung & Samsung \\
\hline Nel & LG G3 & iPad \\
\hline Gus & Blackberry Z3 & ipad \\
\hline
\end{tabular}

Both courses used English as the medium of instruction (but the LMS in Germany was in German), which for the majority of students in both courses was not their mother tongue. Both courses were culturally heterogeneous, with students from several different countries and backgrounds.

As part of the introductory session, students were told that "mobile is part of LIFE, so switching off is not an option", reasons for keeping mobiles on in class as well as potential negatives were then discussed; a slide from the course is shown in Figure 1. The course strives to give students a taste of LIFE (Learning, Innovating, Financing, and Empowering) and options and choices for LIFE. Students used their mobiles to keep in contact with each other, with friends and family, and with the world. One student comment on the LMS read, "this morning when I was reading news in BBC's app on my phone." 


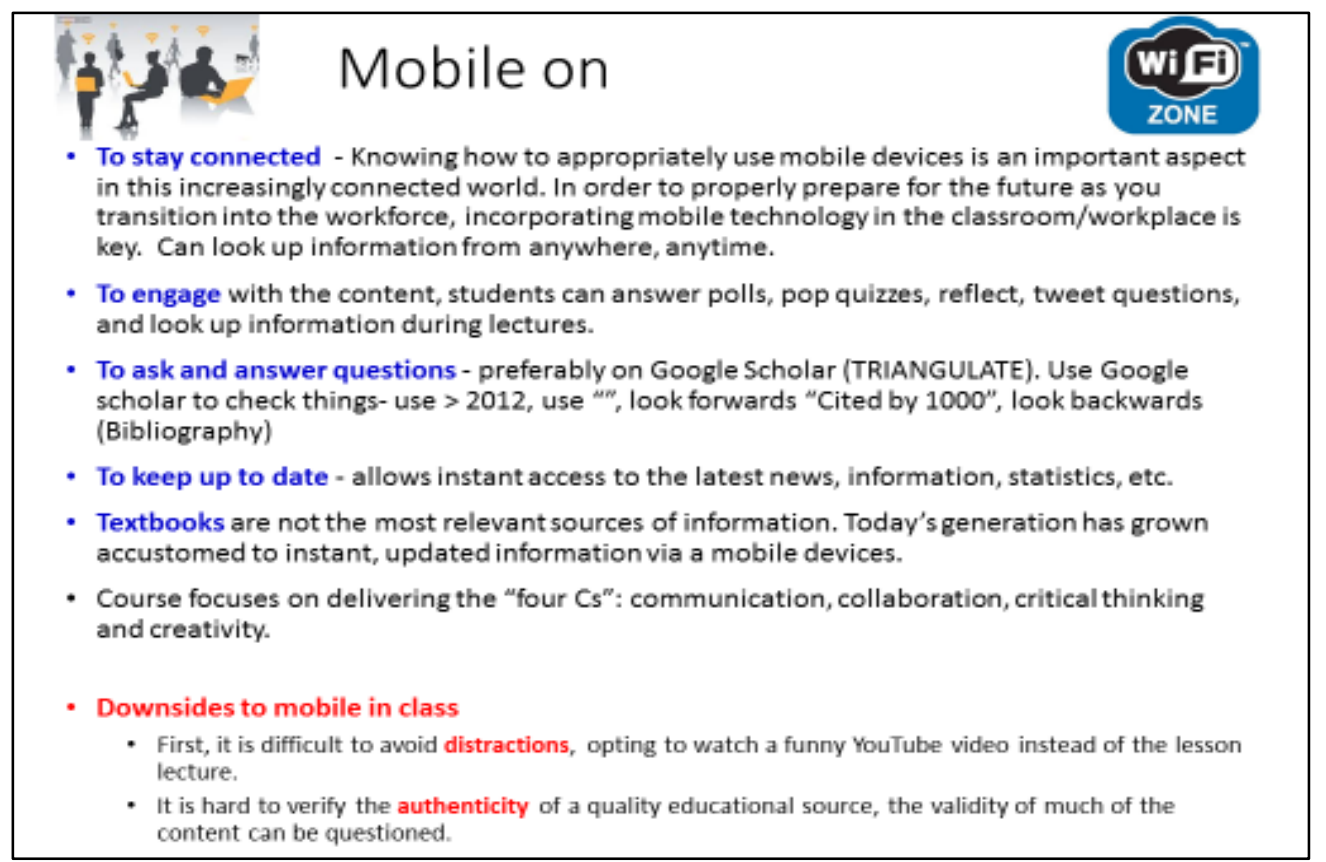

Figure 1: Lecture slide on reasons why mobiles should be on in class

This slide and discussion was introduced into the course after the first time the course was run in 2013, and in course evaluations, several students commented that they were unsure why mobiles had to be on in class. The academic originally thought that as all students were post graduates, it was obvious why mobiles should be on in class. The literature states that students must be tutored on the use of mobile web-enabled devices in the classroom (Nursey-Bray, 2015), and on reflection, the academic would agree.

A new curricula that uses mobile web-enabled devices to enhance face-to-face teaching was built as suggested by Nursey-Bray (2015) which used the Learning Management Systems (LMS) (Sakai in South Africa, and Moodle in Germany) as the central component of the courses. The courses were designed to place the student at the centre of the process, and the LMS was accessible via mobile web-enabled devices in class through free wifi (Conde et al., 2014). The LMS's had a range of integrated applications, many of which were used on the courses.

As can be seen in the column on the left in Figure 2, the LMS's have a large functionality including Announcements, Calendar, Course outline, Resources, Polls, Forums, Blogs, Chat Room, Drop Box, Assignments, Examinations, Gradebooks, Course Evaluations and Videos. Figure 2 has the Resources tab highlighted, and the names of individuals blocked out. Note that students may only respond to Polls, can only submit questions and answers to Forums and Course Evaluations, and can only submit documents to Drop Box, Assignments, and Examinations (Tests and Quizzes). Academics and or Administrators control the LMS. 


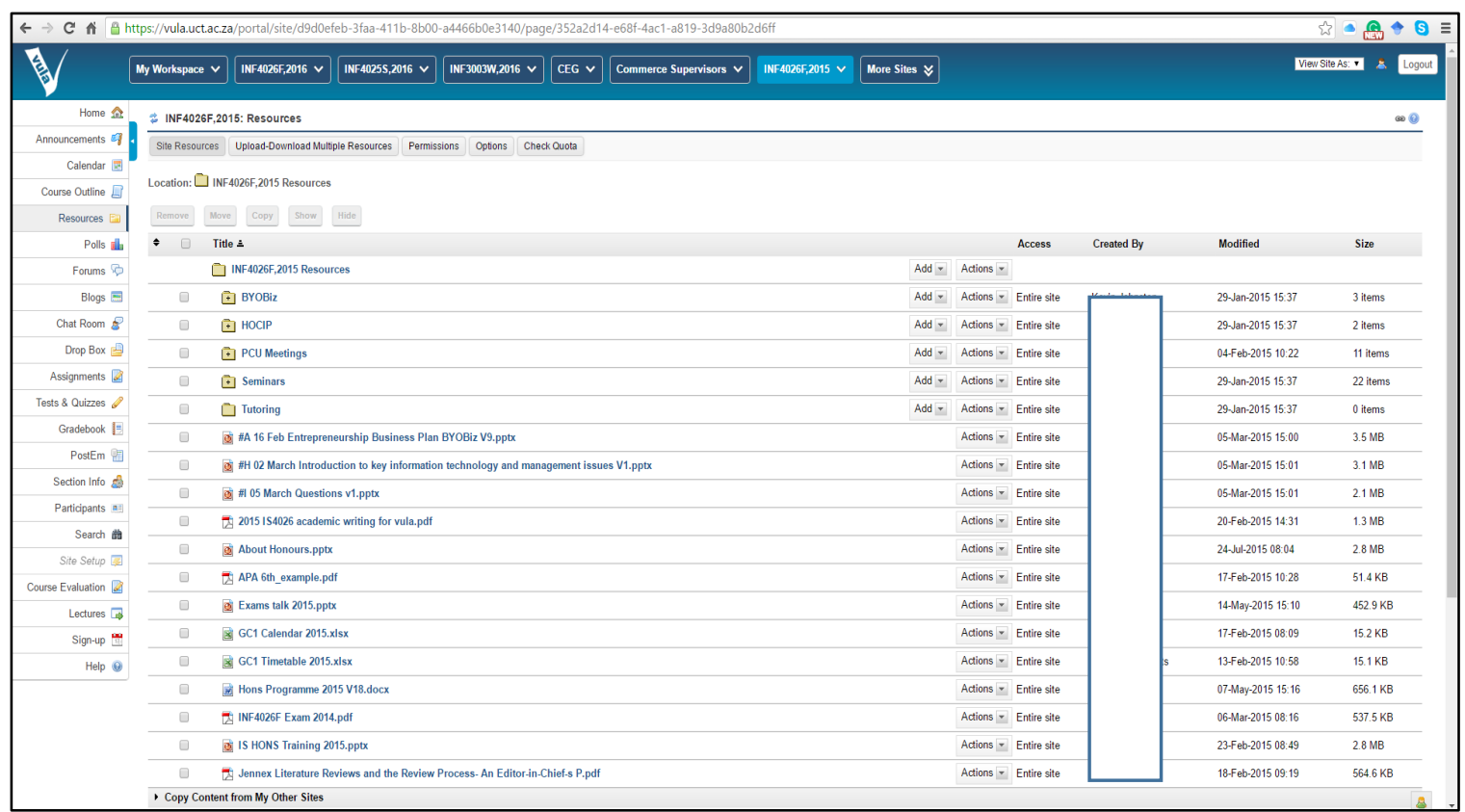

Figure 2: A screenshot of the Resource tab of the Sakai LMS used

This meant that a student who had his/her mobile device on was always connected. Figure 3 shows a screenshot the Moodle LMS used in Germany. Figure 4 shows the resource tab for the same course as shown in Figure 2. As can be seen when comparing Figures 2 and 4, the details are the same, but the formats are different. Each of the functions used in the Sakai LMS will be discussed. The functions in Moodle are similar.

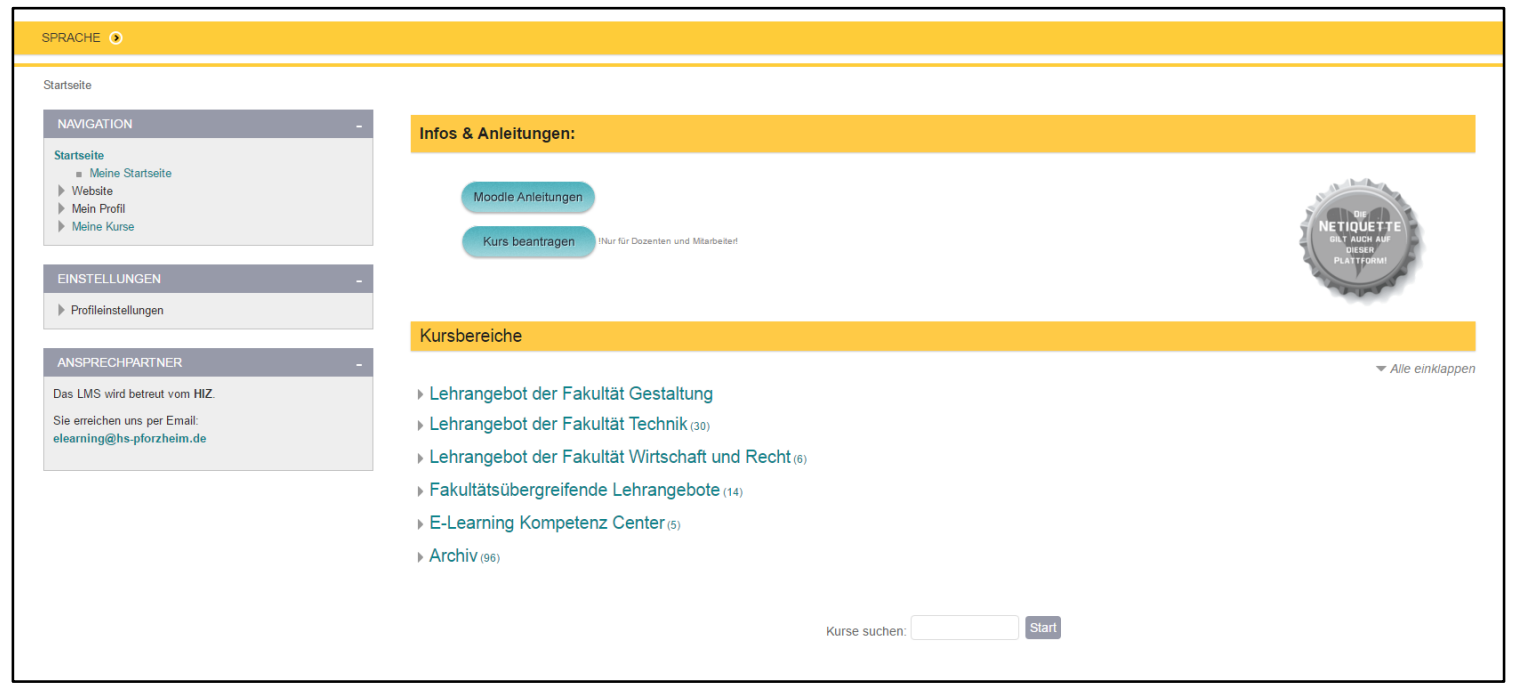

Figure 3: A screenshot of the Moodle LMS used 


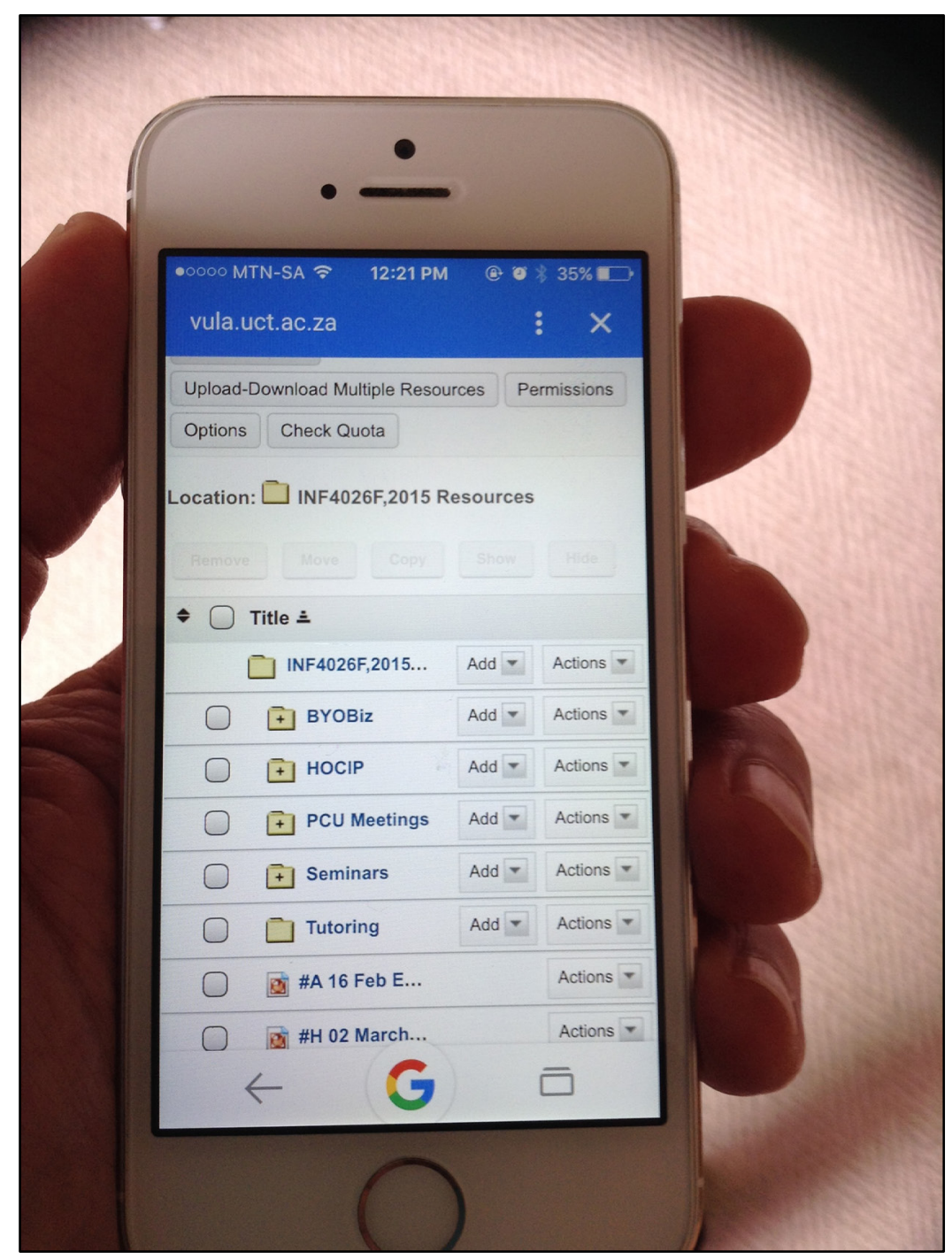

Figure 4: A screenshot of the Resource tab on a Mobile phone

\section{Announcements}

All announcements are announced in class and put on LMS which automatically notifies each student via email. Announcements are quick and easy to do on LMS, and most are done by the academic. A screen shot of some of the Announcements made are shown in Figure 5 (once again details of individuals names have been blanked out). Several students were observed checking announcements in class. 


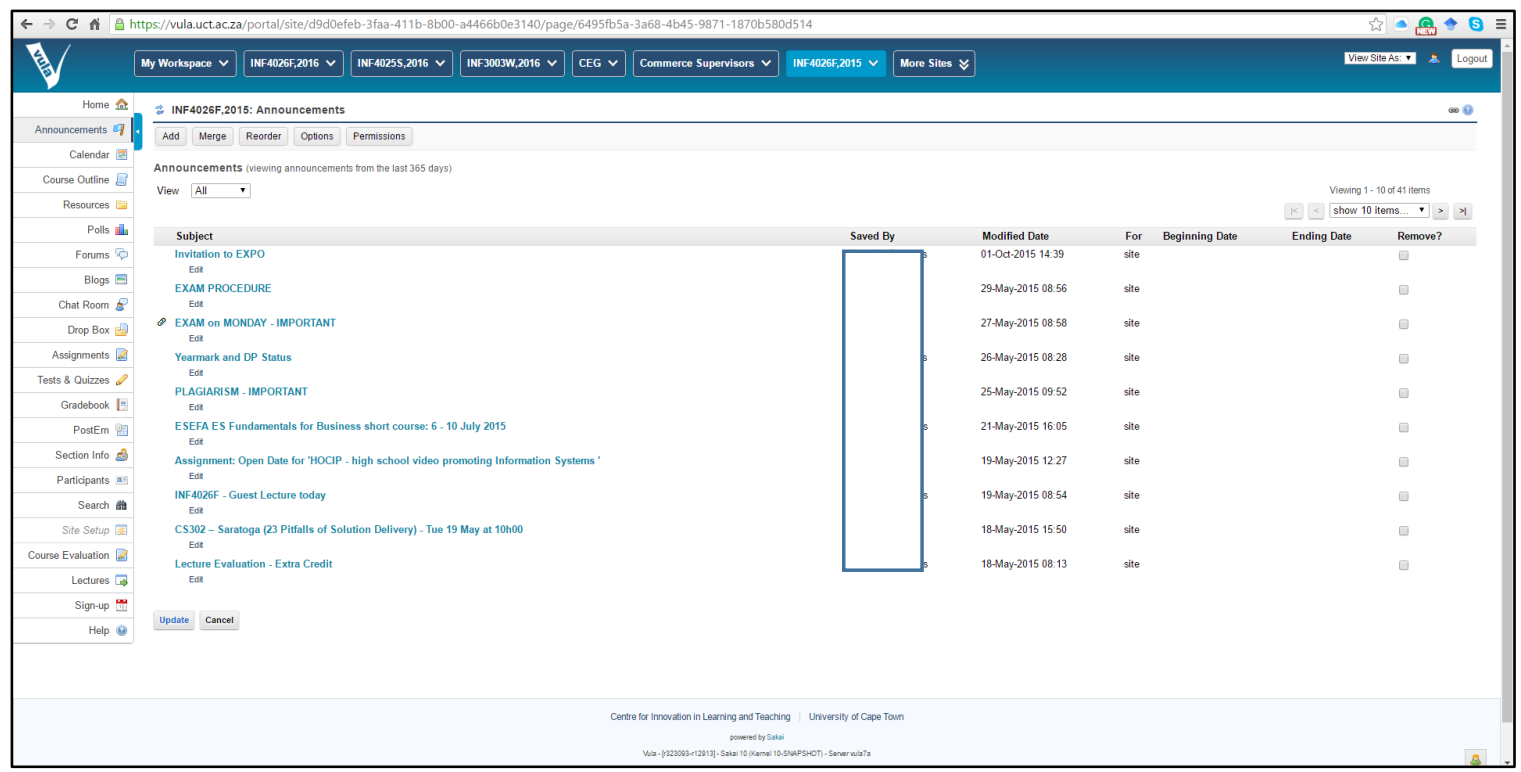

Figure 5: Screen shot of Announcements tab

\section{Course Outline}

The course outline is usually a Word document which is loaded onto the LMS. The first two pages of a course outline are shown in Figure 6, showing the level of detail in the Table of Contents. The course outline is available before the course starts so all students may obtain a clear understanding of the course. The need for transparent and clear learning objectives, deliverables, and grading criteria is important (Clark, 2012), and should be found in the Course Outline. The Course outline can also be created as a Flipping ebook, a touch sensitive document which can be created freely using sites such as http://fliphtml5.com/free-ebook-publisher.php, or http://www.flipbuilder.com/.

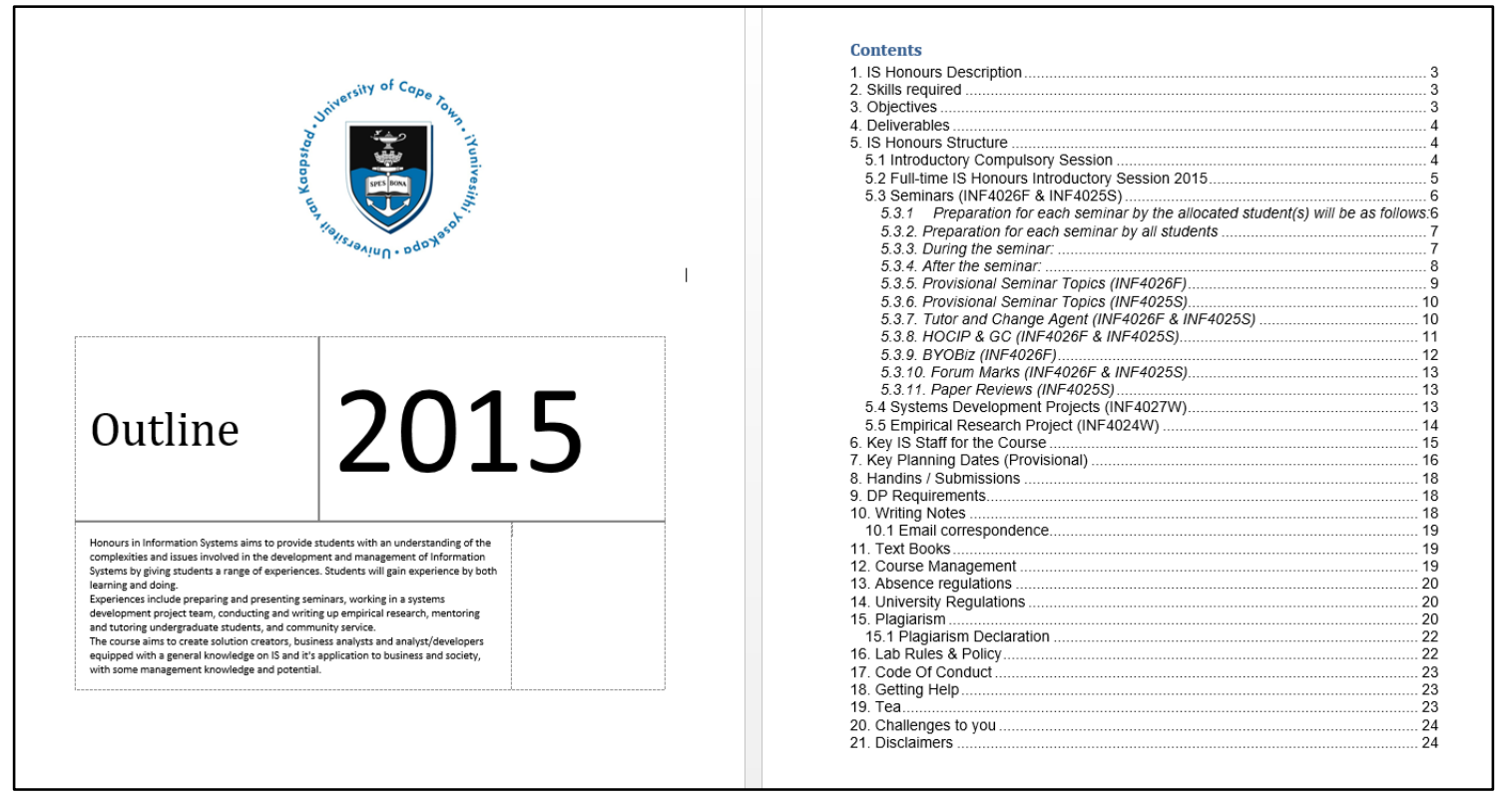

Figure 6: First two pages of Course Outline 


\section{Resources}

All Resources available to students are electronic in both courses and are loaded onto the LMS. In both the courses there are no prescribed text books; students are expected to read a wide range of journal articles and academic literature and to create their own academic resources. Figure 7 shows the resources available for one seminar (T3). Apart from the first Word document (which details scope, guidelines, and literature sources), and the last two PDF documents (which are journal papers), all other documents were created by the students.

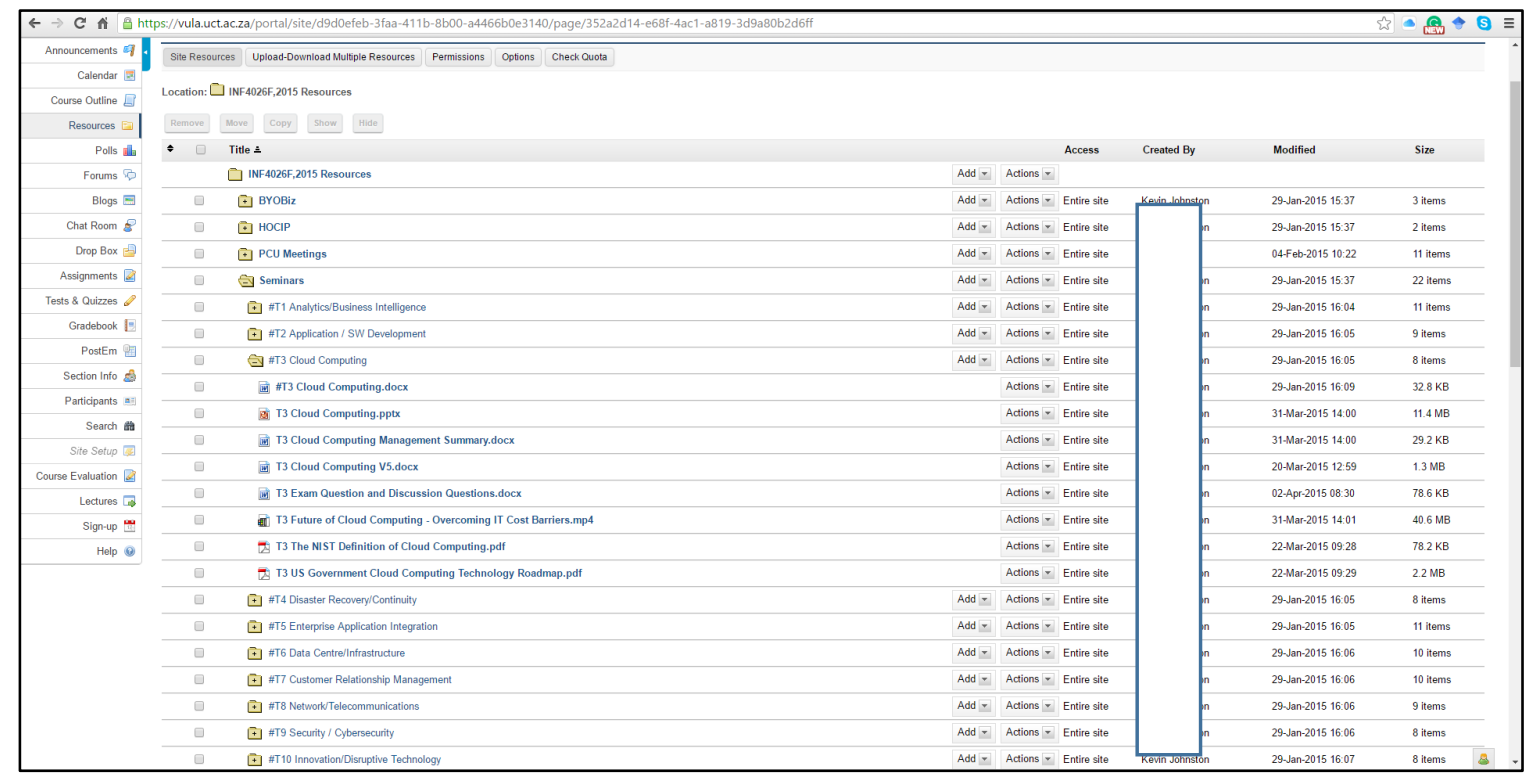

Figure 7: Resources available for a seminar

\section{The process prior to seminars}

The students followed a process before each seminar or classroom session:

- The student(s) allocated to the seminar received the scope of the subject matter, guidelines and literature sources (the first Word document in Figure 7) 4 weeks before their presentation date. The student(s) then carry out a focused literature survey, and summarize the particular body-of-knowledge in the form of a 15-20 page quality literature review paper.

- The literature review must be submitted electronically at least 3 weeks before presentation date as version 1 (V1) to the Drop Box. Only academics or administrators are allowed to upload documents into the LMS Resources tab. The paper is then reviewed and evaluated by peers within 3 days, with suggested corrections highlighted using Track Changes. The students then amend the paper using the Track Changes option and resubmit as version 2 (V2). The academic then evaluates, corrects, adds comments (as shown in Figure 8), and may suggest corrections/additions/deletions to the paper. This process may continue until the academic is satisfied that the paper is a valuable resource for the class (In Figure 7, this is the third Word document labelled as V5 (Version 5)). 


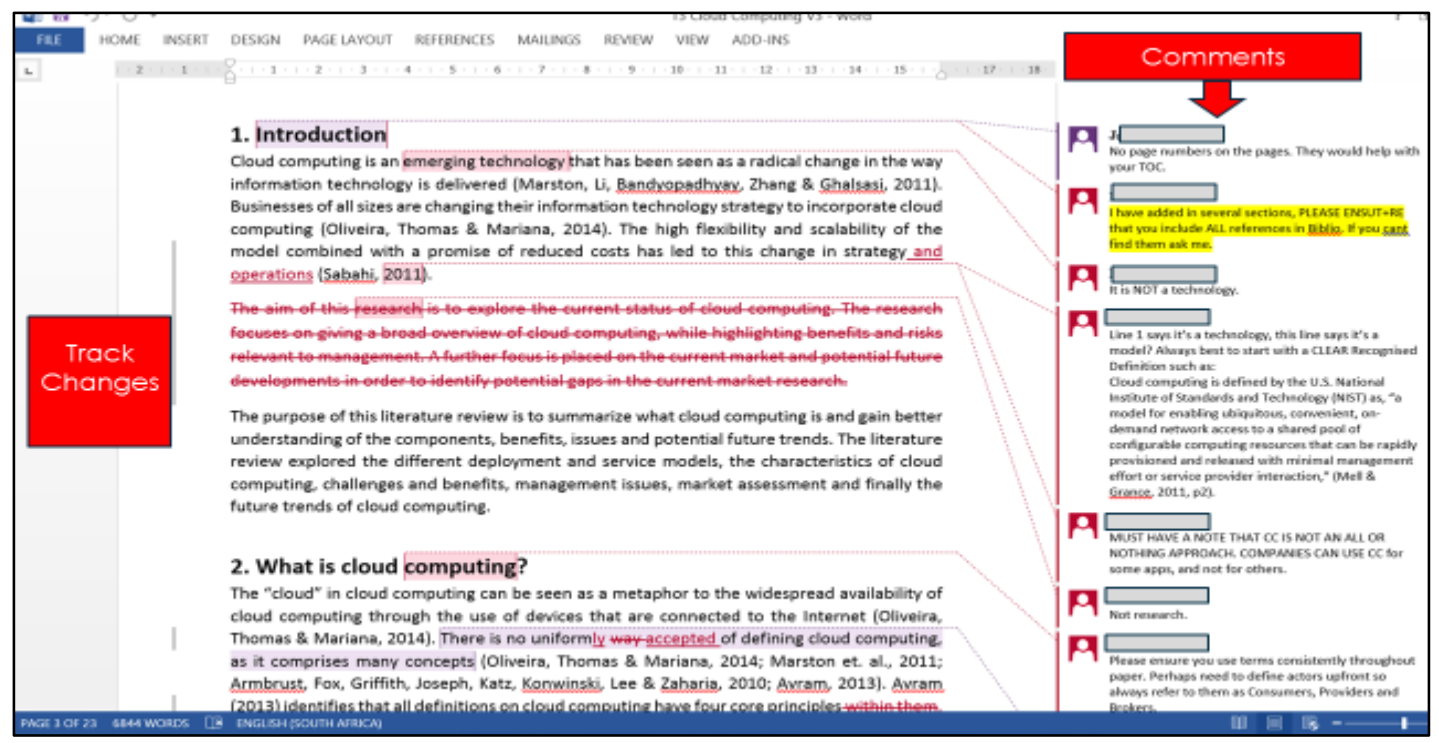

Figure 8: Process of evaluating and correcting student submissions

- The students must source two key research articles from Journals used in the literature review and upload them in PDF form to the Drop Box. The students then prepare an answer to a past exam case study question and prepare discussion questions and examples which are uploaded to the Drop Box at least 3 days before the seminar. Discussion questions must also be put on the Forum.

- The student(s) must prepare a 25-35 minute formal presentation summarizing the major issues and developing further issues beyond the seminar paper. It must not be a straight repeat of the paper, and it must be loaded onto the Drop Box as shown in Figure 7.

- A short (4-5 minute) video must be loaded onto the Drop Box as shown in Figure 7.

All students are expected to have read the paper, articles, and Forum questions and answers before each seminar. Students are encouraged to analyse the paper, articles, and questions and answers in groups before each seminar.

\section{The process in seminars (class)}

Each seminar session is recorded, and the vodcast made available to the class on the LMS under the Lectures tab. The first 25-35 minutes of the seminar consists of the presentation by the student(s). The next 25-35 minutes of the seminar consists of the presentation and discussion of the case study question and answer and the Forum discussion questions. Students were observed using their mobiles to check up on what they (and others had) posted on the Forum and to make posts during the seminar. Questions relating to the presentation may be put to the speaker(s) by the class and vice versa. Students are expected to provide prepared answers to pre-prepared discussion questions. Students are encouraged to conduct quick Polls in the class.

After the seminar the student(s) must produce a Management Summary of no more than 5 pages of the body-of-knowledge, and this must be loaded onto the LMS as shown in Figure 7. This is used for future learning purposes.

\section{Polls}

From time to time Polls are taken in class on Mentimeter.com. Mentimeter allows an academic or student to set up a polls, pop quizzes (short quiz without warning or announcement), ask open- 
ended questions, ask multiple choice questions (MCQs) easily and quickly. Students are then given a minute or two to respond using their mobile devices as shown in Figure 9.

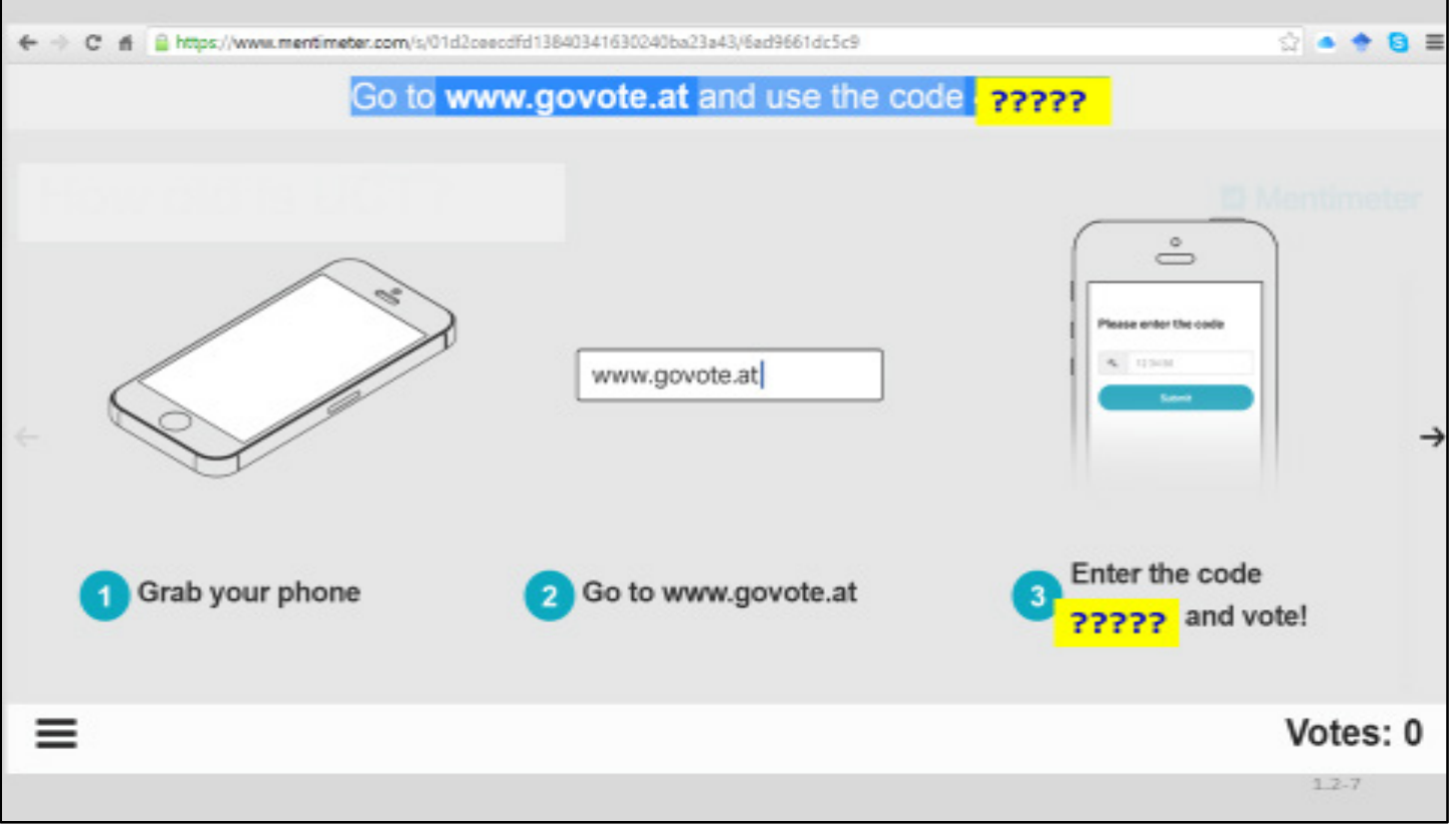

Figure 9: Mentimeter application screenshot

The results may be displayed in real-time, so students can see voting patterns, or one can wait until all students have responded before displaying the results. The results can then be assessed, and positives reinforced (Clark, 2012). Students embraced Mentimeter and appeared to enjoy using it on their phones in class to ask MCQs and to take snap polls. Mentimeter can show what percentage of the class has responded, and polls were usually closed when over $80 \%$ of the class had responded.

\section{Forums}

The questions and answers loaded onto the Forums form a vital part of the courses, and students may ask and answer questions at any time using their mobile devices. All students are expected to have read the Forum questions (and are assessed for doing so); students are also expected to be active members of the Forum and respond to questions and to create new questions (also assessed). The assessment is to make students active rather than passive members of the forum (Smith \& Smith, 2014). The Forum questions and answers are discussed in class; an example is shown in Figure 10. The Forum is one area (apart from Chat Room and Drop Box) to which students can post directly. Most students were observed using mobile phones to check on the Forum during class, usually to look at their posts, as they were often asked to defend or elaborate on a post. Several students were seen to add new posts during class. Tablets and laptops were used more often to view the Forum in class, possibly because of screen size. 


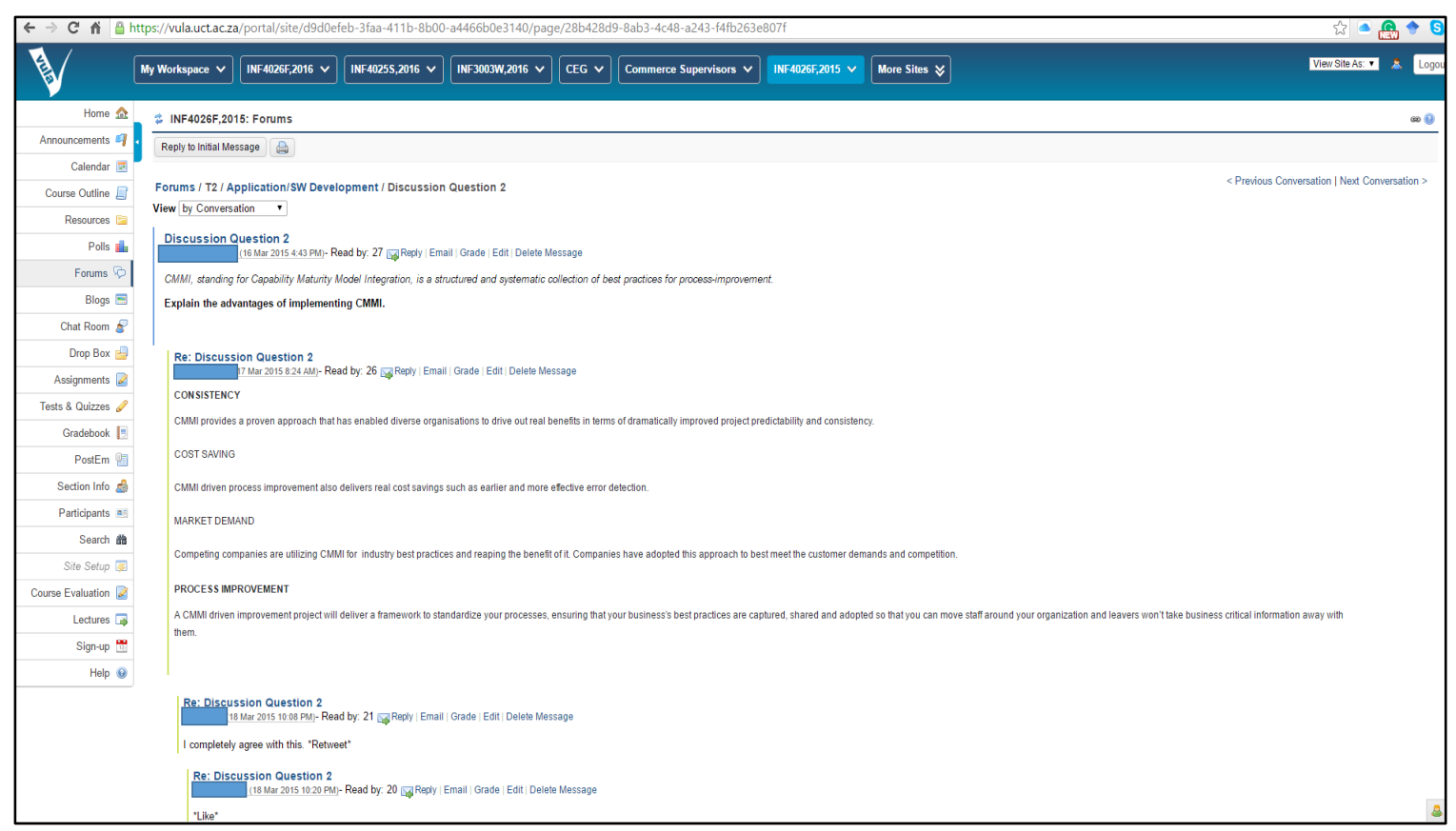

Figure 10: Examples of Forum questions and answers

\section{Blogs}

Students were allowed to create blogs which they could put on the LMS as shown in Figure 5, but perhaps because Blogs were not assessed in this course, the students did not share them. No students were observed using Blogs in class.

\section{Chat Room}

Students were told that the Chat Room was their domain, and they could raise and discuss any issues they wished without censure. As can be seen in Figure 11, some of the chats were around political issues happening on campus at the time. There were no negative comments around the use of mobiles in the classroom. There was limited use in the classroom, and less that $5 \%$ of posts were made during class, and the posts made were usually seeking clarification.

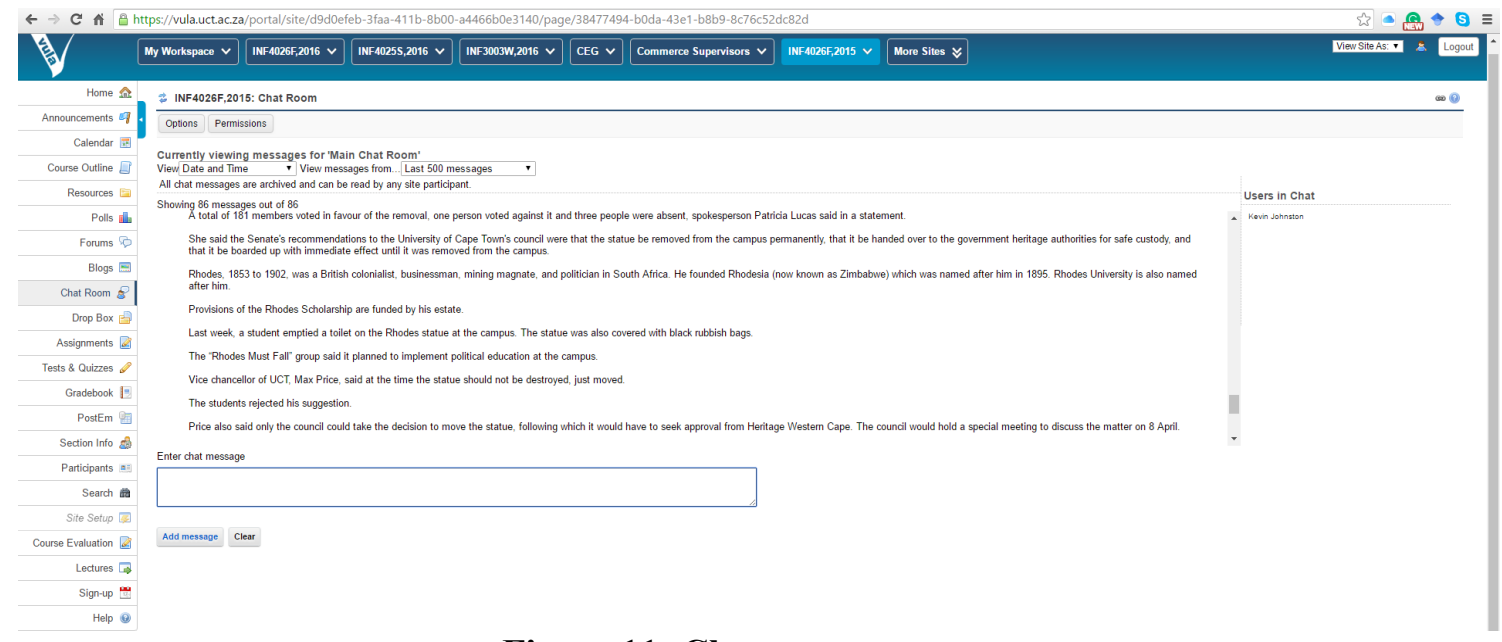

Figure 11: Chat room messages 


\section{Drop Box}

Students used Drop Box to share documents with academics and fellow students. Academics or administrators then move checked documents to other tabs in the LMS. Drop Box enables students and academics to synchronize, store, retrieve, and share documents and files across mobile devices and PCs. Students were strong supporters of Drop box in both courses, but this was seldom used in class.

\section{Assignments}

All handins/submissions are electronic to the LMS, and must be submitted by $12 \mathrm{~h} 00$ on the due date. Students can see all Assignments due for entire Course, with due dates as shown in Figure 12. Academics and Administrators can see the number of submissions made, including late submissions. Submissions can be marked electronically or, if required, printed. This function was seldom seen to be used in class.

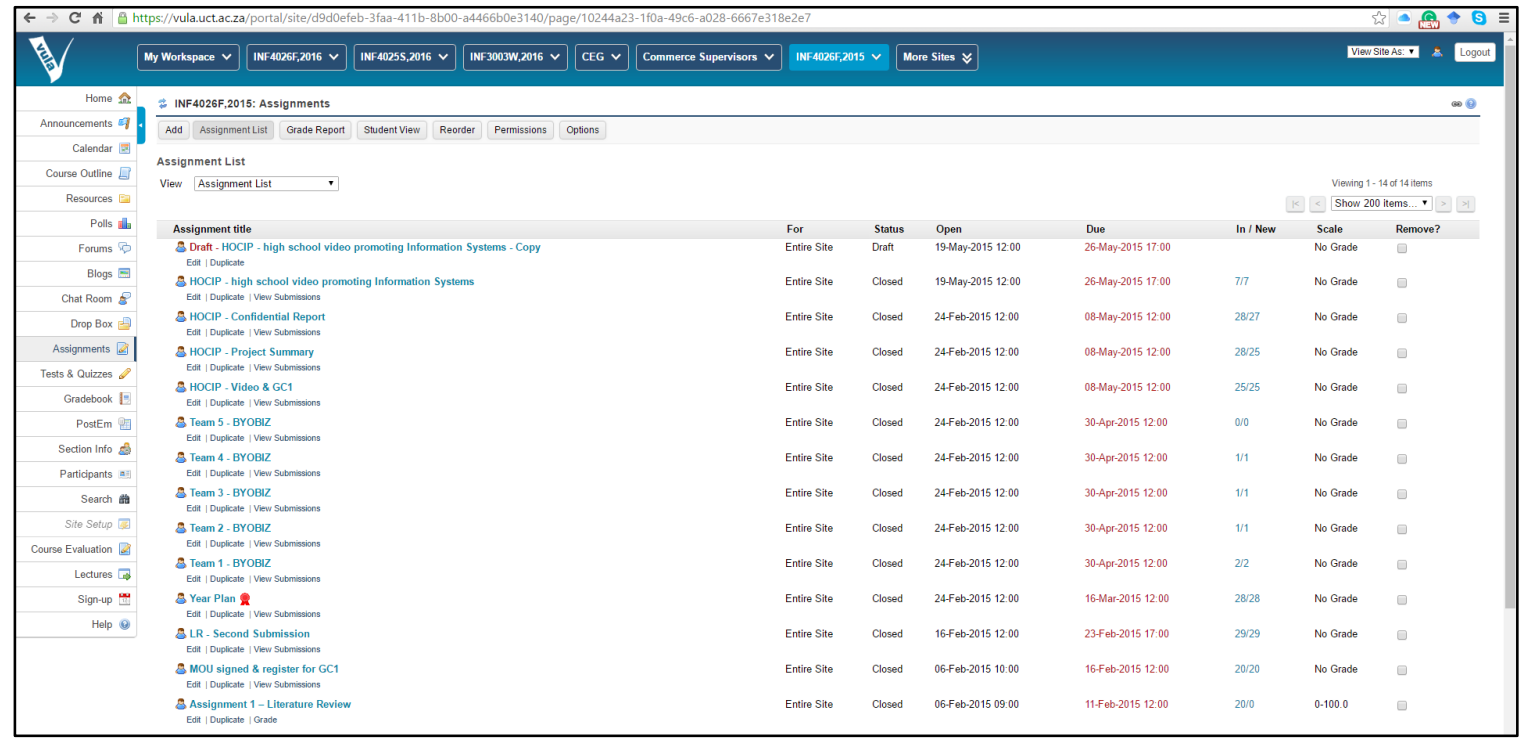

Figure 12: Assignments tab

\section{Examination}

Students are given an electronic copy of a case study 48 hours before the exam on the LMS. It is suggested that students work in teams and share information about the case. Students are advised to prepare possible answers to possible questions. On the day of the examination, students are given some additional information on the case study as well as the questions. The examination is an open book examination and is done on a PC in a laboratory, and submitted to the LMS as shown in Figure 13. Students were exposed to remote proctoring systems such as ProctorFree and ProctorU (Eisenberg, 2013). Students were allowed the option to write their exams using ProctorU at one of the Universities (two students chose to do so). These systems "remotely track every mouse click and keystroke of test-taking students" (Eisenberg, 2013, p. 1). 


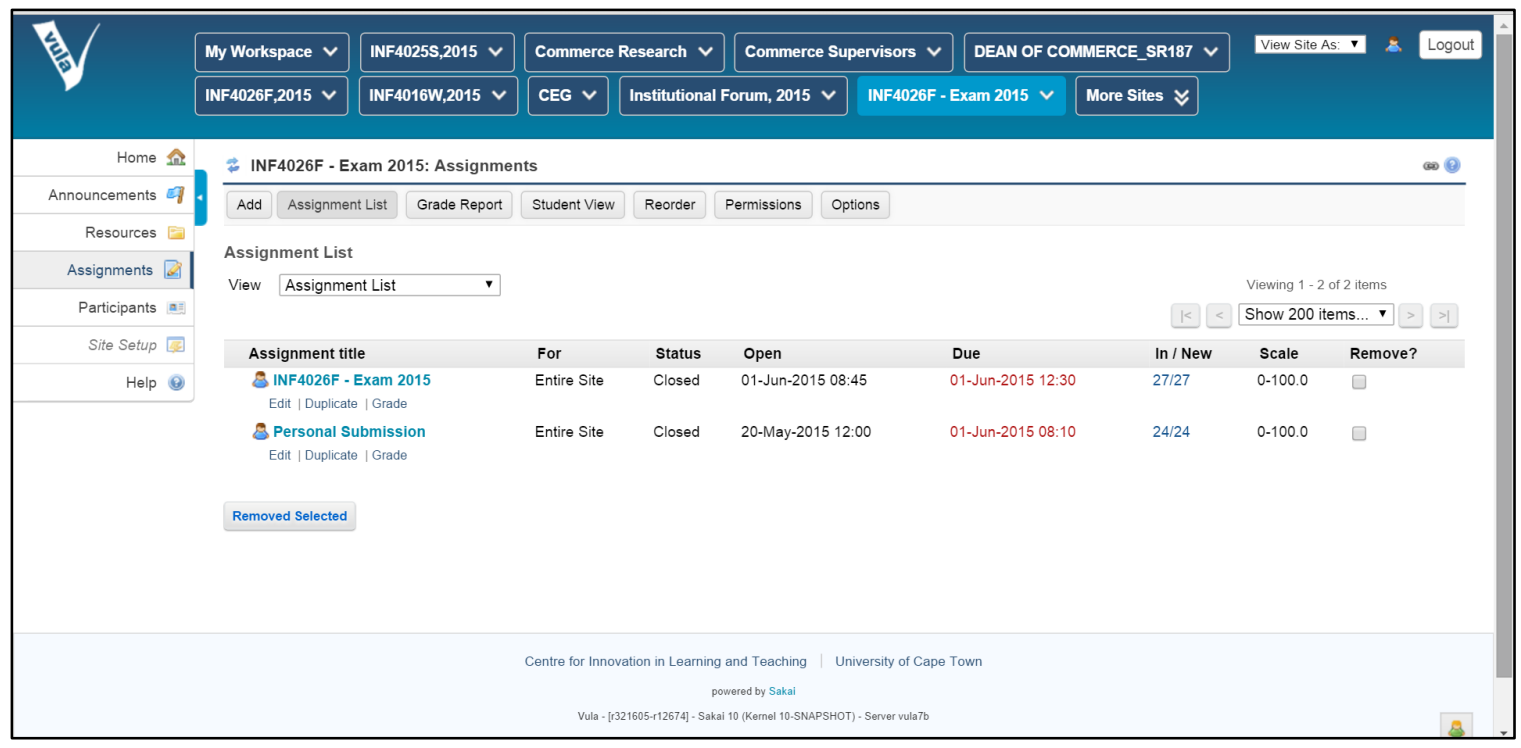

Figure 13: Examination tab

\section{Gradebooks}

Each student's gradebook is published on the LMS, and each student can see only his/her marks. Students are encouraged to check their marks and raise any issues within seven days of being notified of the results. Students were not observed accessing their Gradebooks during class, but several were observed acing their Gradebooks after class.

\section{Course Evaluations}

Course Evaluations are set up on the LMS, and all students encouraged to complete the evaluation. All student submissions are anonymous. Once submission is closed, the results of the course evaluation are published on the LMS as shown in Figure 14. There were no complaints or negative comments about the use of mobiles in the classroom by students or staff, nor were there any positive comments - students seemed to accept or accept mobiles in the classroom.

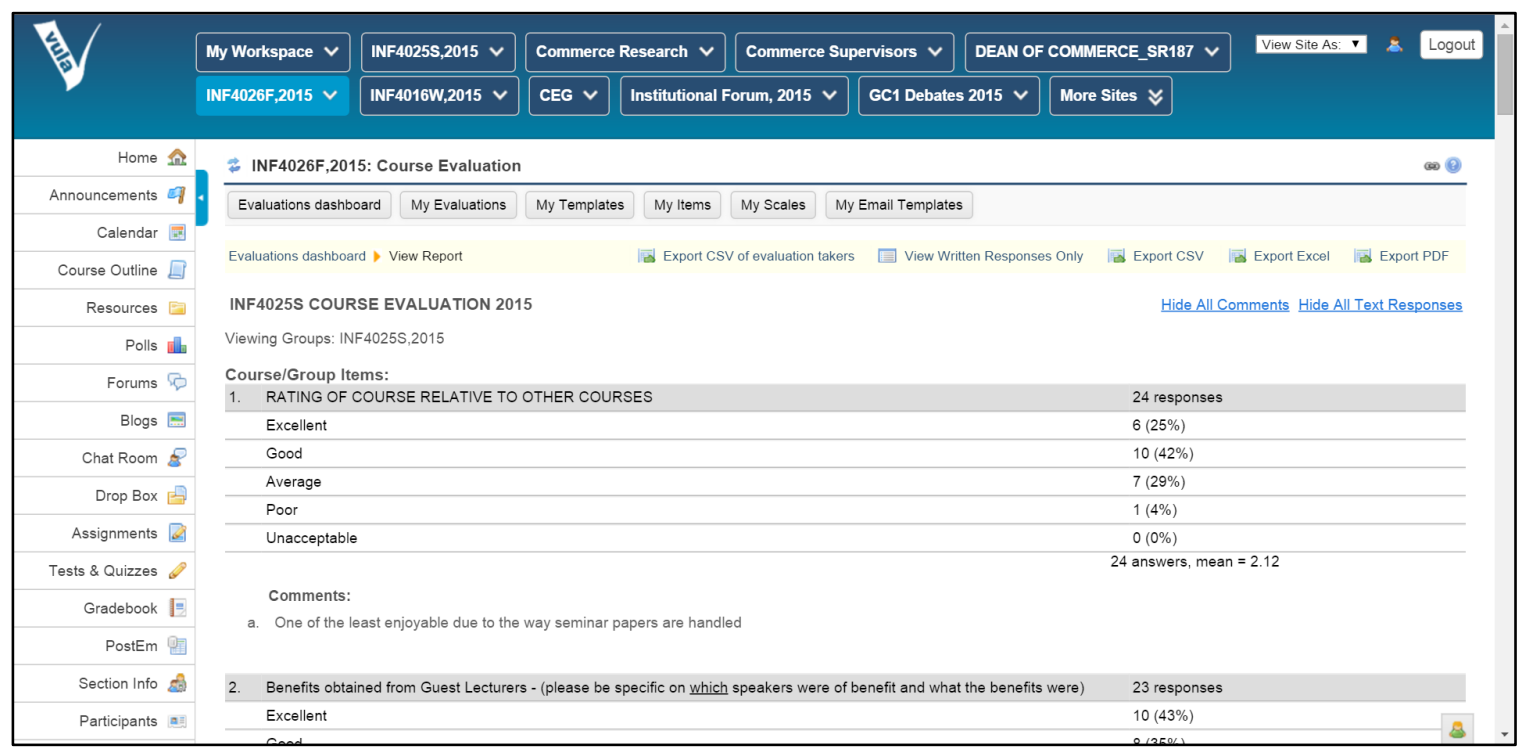

Figure 14: Course Evaluation 


\section{Videos}

Each seminar is automatically video recorded (vodcasts), and then posted onto the LMS by classroom facilities as shown in Figure 15. Students then access the vodcasts in whole or in part to clarify issues, or as a revision tool.

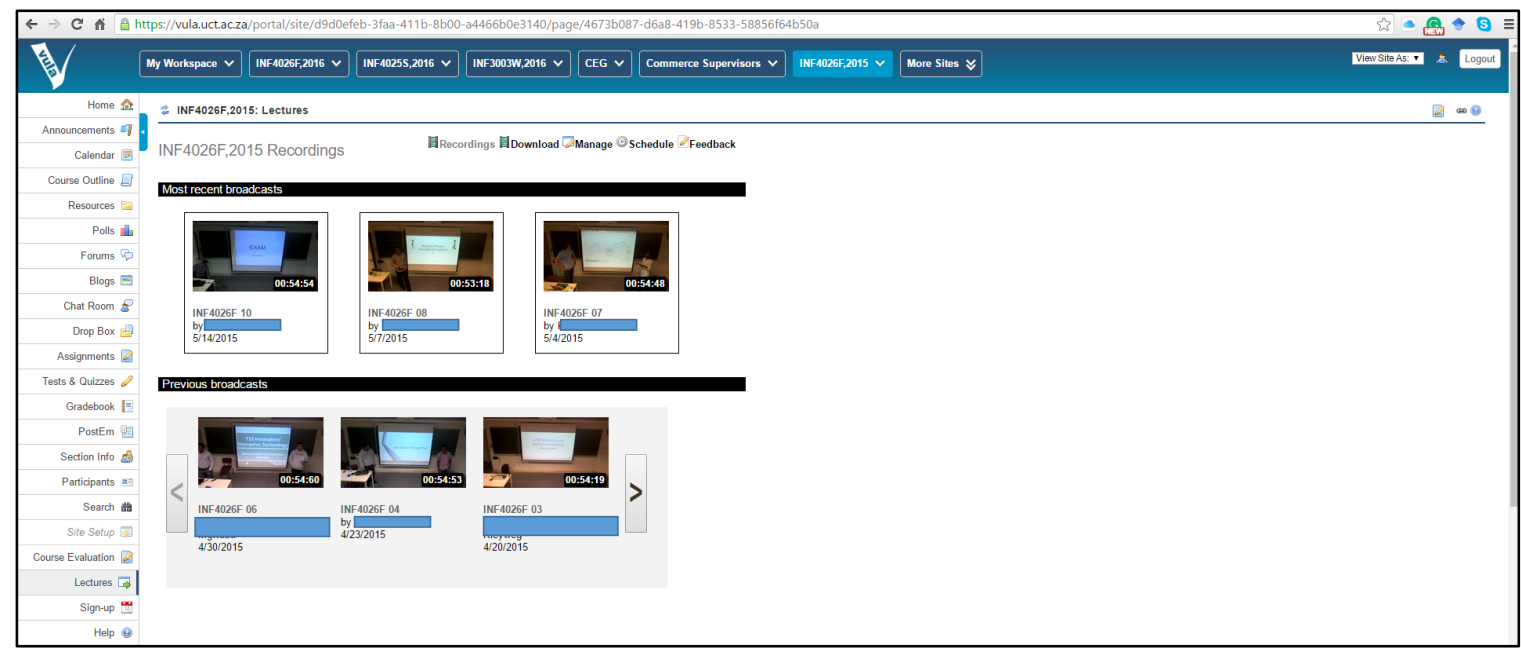

Figure 15: Vodcasts available on the LMS

Students were observed accessing the vodcasts in whole or in part in class, some used tablets to watch the videos, as they said it was easier to watch than on the screen, and one student pointed out that had she hearing problems, so she listened to the vodcast through headphones. Usage statistics showed that each vodcast was downloaded an average of 8.5 times, a much lower rate than reported for undergraduate students by Johnston (2013). No statistics were available on the number of times the videos shared by students were watched.

\section{Social Networking Systems (SNS)}

Many students were observed checking their Social Networking Systems (SNS): Facebook and Twitter in particular. While the main uses of SNS were seen to be socializing, several students used SNS's to arrange study groups and meetings as mentioned in the literature (Alarabiat \& AlMohammad, 2015; Johnston et al., 2013). SNSs appeared to be used when students' interest in a topic waned, or when they received a message in class. In most cases messages were dealt with quickly with a few keystrokes, although a few students did engage in prolonged conversations. The other SNSs the students were observed using outside of the class room were Skype and WhatsApp.

\section{Discussion}

All students were observed using mobile web-enabled devices in two classrooms for a range of activities, including to check announcements, respond to class polls, check their submissions to Forums, access documents in the Drop Box, translate presentation slides, and watch videos. The majority (over 80\%) used their mobile phones to answer polls, while most used laptops or tablets to access Forums in class. This answered the first research question - How are mobile webenabled devices used in classrooms in two Universities?

The second question, what is the impact of mobile web-enabled devices in classrooms in two Universities, was not as straight forward. Mobile devices did not negatively impact the class; no calls were received or made during any of the classes. Students used mobile devices to take and make notes during the classes. The students appeared to be more engaged and comfortable know- 
ing they were allowed to openly access their mobile devices. The collaboration between students appears to have improved, as students were observed reminding students of past discussions. From an academics perspective, apart from the preparation, the impact in the classroom was negligible. An area that needs investigation is the impact on the learning outcomes, and results.

One of the unintended consequences was the use of mobile phones to translate text into home languages in class. Students often took photographs of slides, which they then translated on their mobile phones using apps such as Google Translate. A second unexpected consequence that was not one phone call (or disturbance of any kind) was made or received during either course. The attitude of the students in both universities was extremely positive and respectful towards each other and the academic.

\section{Conclusion}

It is difficult to understand why any academic would not want to embrace and use mobile webenabled devices in and out of the classroom. A well planned course based on an LMS and incorporating mobiles offers many benefits. The main benefits are of having an engaged and interested group of students. Some of the additional benefits include being paperless (and 'Green' - the right thing to do), never losing a handin or exam paper, being able to read every handin and exam paper, being able to access all documents/assignments etc., from anywhere at anytime. Course outlines can be created as Flipping ebooks which make them even more mobile friendly and easy to use, plus being paperless saves money, and as the world is in austerity mode at present this makes sense.

Similarly, it is difficult to understand why any student would not want to use his/her mobile webenabled devices in and out of the classroom. Each student already has a mobile web-enabled device of his/her own, so no need for any new devices or training. No handin or exam paper is ever lost, marks are not lost in exams due to a student's poor handwriting, and all documents are available at any time from anyplace. There were no complaints or negative comments from either course about the use of mobiles in the classroom by students or staff.

\section{Acknowledgments}

This work is based on the research supported in part by the National Research Foundation of South Africa (Grant Number 91022).

\section{References}

Abachi, H. R., \& Muhammad, G. (2014). The impact of m-learning technology on students and educators. Computers in Human Behavior, 30, 491-496.

Alarabiat, A., \& Al-Mohammad, S. (2015). The potential for Facebook application in undergraduate learning: A study of Jordanian students. Interdisciplinary Journal of Information, Knowledge, and Management, 10, 81-103. Retrieved from http://www.informingscience.org/Publications/2283

Al Hamdani, D. S. (2014). A constructivist approach to a mobile learning environment. International Journal of Computer Applications, 93(4), 41-46.

Bafna, K. M. (2014). Using technology in engineering education. QScience Proceedings (World Congress on Engineering Education 2014) 2015:7. http://dx.doi.org/10.5339/qproc.2015.wcee2014.7

Barjis, J., Gupta, A., Sharda, R., Bouzdine-Chameeva, T., Lee, P. D., \& Verbraeck, A. (2012). Innovative teaching using simulation and virtual environments. Journal of Information, Knowledge, and Management, 7, 237-255. Retrieved from http://www.informingscience.org/Publications/1750

Benham, H., Carvalho, G., \& Cassens, M. (2014). Student perceptions on the impact of mobile technology in the classroom. Issues in Information Systems, 15(2), 141-150. 
Brophy, K. (2015). Gamification and mobile teaching and learning. Handbook of Mobile Teaching and Learning, 91-105. Zhang, Yu (Aimee) (Editor). Springer Berlin Heidelberg.

Burton, A. (2015). Lecturers' experiences of using wikis to support student group work. Innovative Practice in Higher Education, 2(2).

Carter, B. L. (2014). Impact of mobile devices on student performance in an agriscience classroom. Instructional Technology Education Specialist Research Papers. Paper 13. http://digitalcommons. georgiasouthern.edu/edu-papers/13

Clark, I. (2012). Formative assessment: Assessment is for self-regulated learning. Educational Psychology Review, 24(2), 205-249.

Cobcroft, R. S., Towers, S. J., Smith, J. E., \& Bruns, A. (2006). Mobile learning in review: Opportunities and challenges for learners, teachers, and institutions. In Proceedings Online Learning and Teaching (OLT) Conference 2006, pages pp. 21-30, Queensland University of Technology, Brisbane.

Coldwell, J., Craig, A., \& Goold, A. (2011). Using eTechnologies for active learning. Journal of Information, Knowledge, and Management, 6, 95-106. Retrieved from http://www.informingscience.org/Publications/1367

Conde, M. Á., García-Peñalvo, F. J., Rodríguez-Conde, M. J., Alier, M., Casany, M. J., \& Piguillem, J. (2014). An evolving Learning Management System for new educational environments using 2.0 tools. Interactive Learning Environments, 22(2), 188-204.

Eisenberg, A. (2013). Keeping an eye on online test-takers. New York Times, 2. Available at http://www.immagic.com/eLibrary/ARCHIVES/GENERAL/GENPRESS/N130302E.pdf

Fischer, N., \& Smolnik, S. (2014). Blessing or curse? Towards an integrated framework of the net effect of mobile IS/IT use in organizations. Available at http://aisel.aisnet.org/icis2014/proceedings/ISStrategy/43/

Franklin, A. (2015). The unintended consequences of the technology in clinical settings. In Cognitive Informatics for Biomedicine (pp. 241-258). Springer International Publishing.

Gerpott, T. J., \& Thomas, S. (2014). Empirical research on mobile Internet usage: A meta-analysis of the literature. Telecommunications Policy, 38(3), 291-310.

Gill, G., \& Bhattacherjee, A. (2009). Whom are we informing? Issues and recommendations for MIS research from an informing sciences perspective. MIS Quarterly, 217-235.

Guerrero, M. (2012). The use of Skype as a synchronous communication tool between foreign language college students and native speakers. HOW Journal, 19(1), 33-47.

Hwang, G., \& Chang, H. (2011). A formative assessment-based mobile learning approach to improving the learning attitudes and achievements of students. Computers and Education, 56(4), 1023-1031.

Inal, S., Kelleci, M., \& Canbulat, N. (2012). Internet use and its relation with the academic performance for a sample of high school students. HealthMed, 6(5), 1643-1650.

Ishak, W. H. W., Yamin, F. M., \& Ibrahim, A. (2014). Students acceptance on document sharing through online storage system. Proceedings of 6th International Conference on Education and Information Management (ICEIM-2014), 68-73.

Jovanovic, J., \& Chiong, R. (2012). Introduction to the special section on game-based learning: Design and applications. Interdisciplinary Journal of Information, Knowledge, and Management, 7, 201-203. Retrieved from http://www.informingscience.org/Publications/1747

Jovanovic, J., Chiong, R., \& Weise, T. (2012). Social networking, teaching, and learning: Introduction to special section on social networking, teaching, and learning (SNTL). Interdisciplinary Journal of Information, Knowledge, and Management, 7, 39-43. Retrieved from http://www.informingscience.org/Publications/1576 
Johnston, K. A. (2013). A guide to educating different generations in South Africa. Issues in Informing Science and Information Technology, 10, 261-273. Retrieved from http://www.informingscience.org/Publications/1810

Johnston, K. A., Chen, M-M, \& Hauman, M. (2013). Changes in use, perception and attitude of Facebook and Twitter. Electronic Journal of Information Systems Evaluation (EJISE), 16(3), pp200-210

Junco, R., \& Cotten, S. R. (2011). Perceived academic effects of instant messaging use. Computers \& Education, 56(2), 370-378.

Karl, K., \& Peluchette, J. V. (2011). "Friending" professors, parents and bosses: A Facebook connection conundrum. Journal of Education for Business, 86(4), 214-222.

Kuznekoff, J. H., Munz, S., \& Titsworth, S. (2015). Mobile phones in the classroom: Examining the effects of texting, twitter, and message content on student learning. Communication Education, (ahead-ofprint), 1-22.

Lekshmipriya, R. K., Kumar, A., Mahadevan, D., \& Bijlani, K. (2016). Classroom collaboration using an in-home gaming device. In Emerging Research in Computing, Information, Communication and Applications (pp. 265-277). Springer India.

Lepp, A., Barkley, J. E., \& Karpinski, A. C. (2014). The relationship between cell phone use, academic performance, anxiety, and satisfaction with life in college students. Computers in Human Behavior, 31, 343-350.

Ley, B., Ogonowski, C., Hess, J., Reichling, T., Wan, L., \& Wulf, V. (2014). Impacts of new technologies on media usage and social behaviour in domestic environments. Behaviour \& Information Technology, 33(8), 815-828.

Markus, M., \& Robey, D. (2004). Why stuff happens: Explaining the unintended consequences of using IT. In K. V. Andersen \& M. T. Vendelø (Eds.), The past and future of Information Systems (pp. 61-93). Oxford: Elsevier Butterworth-Heinemann.

Morgan, J., \& Ravindran, S. (2014). An examination of home internet and mobile device use in the U.S. Interdisciplinary Journal of Information, Knowledge, and Management, 9, 1-18. Retrieved from http://www.informingscience.org/Publications/1935

Munzur, Z. (2013). Technology is our friend: Using technology to teach english learning strategies. Journal of Education, 4, 51-64.

Ngafeeson, M. N., \& Sun, J. (2015). The effects of technology innovativeness and system exposure on student acceptance of e-textbooks. Journal of Information Technology Education: Research, 14, 55-71. Retrieved from http://www.informingscience.org/Publications/2101

Nursey-Bray, M. (2015). Moving with mobiles: Using IT in the classroom as against online: A comparative reflection from South Australia. Handbook of Mobile Teaching and Learning, 741-751. Ed (Yu (Aimee) Zhang), Springer-Verlag, Berlin Heidelberg.

Petersen, C., \& Johnston, K. A. (2015). The impact of social media usage on the cognitive social capital of university students. Informing Science: the International Journal of an Emerging Transdiscipline, 18, 1-30. Retrieved from http://www.informingscience.org/Publications/2160

Power, T. (2014). Educational technology: Evidence of impacts on teaching and learning. Findings and recommendations from the DFID topic guide on educational technology, 2014. In Education, Technology and Women. Key Issues in Development, 16-17 September 2014, Dhaka, Bangladesh.

Roblyer, M. D., McDaniel, M., Webb, M., Herman, J., \& Witty, J. V. (2010). Findings on Facebook in higher education: A comparison of college faculty and student uses and perceptions of social networking sites. The Internet and Higher Education, 13(3), 134-140.

Roodt, S., de Villiers, C., Johnston, K., Ophoff, J., \& Peier, D. (2014). YouTube as an academic tool for ICT lecturers. Proceedings of the e-Skills for Knowledge Production and Innovation Conference 2014. 
Ruggiero, D., \& Mong, C. J. (2015). The teacher technology integration experience: Practice and reflection in the classroom. Journal of Information Technology Education: Research, 14, 161-178. Retrieved from http://www.informingscience.org/Publications/2227

Saunders, M., Lewis, P., \& Thornhill, A. (2009). Research methods for business students (5th ed.). London: Pearson Education/Prentice Hall.

Smith, D., \& Smith, K. (2014). The case for 'passive' learning - The 'silent' community of online learners. European Journal of Open and Distance Learning. Retrieved from http://www.eurodl.org/materials/contrib/2014/Smith_Smith.pdf

Tarafdar, M., Gupta, A., \& Turel, O. (2013). The dark side of information technology use. Information Systems Journal, 23(3), 269-275.

Wu, Y. J., Outley, C., Matarrita-Cascante, D., \& Murphrey, T. P. (2015). A systematic review of recent research on adolescent social connectedness and mental health with internet technology use. Adolescent Research Review, 1-10.

\section{Biography}

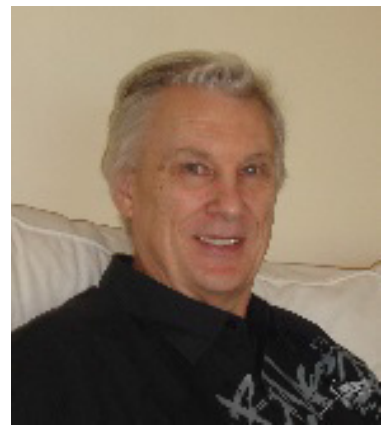

Kevin Johnston is an Associate Professor and head of the Department of Information Systems at the University of Cape Town. He worked for 24 years for companies such as De Beers, Liberty Life, Legal \& General and BoE. Kevin's main areas of research are ICT Strategic Management, IS educational issues, IS-related social issues and Open Source Software. 